\title{
Effect of dietary cation-anion difference on performance of lactating dairy cows and stability of milk proteins
}

\author{
C. M. M. R. Martins, ${ }^{*}$ M. A. Arcari, ${ }^{*}$ K. C. Welter, $†$ A. S. Netto, $†$ C. A. F. Oliveira, $\ddagger$ and M. V. Santos ${ }^{* 1}$ \\ *Department of Nutrition and Animal Production, School of Veterinary Medicine and Animal Sciences, \\ †Department of Animal Science, and \\ $\ddagger$ Department of Food Engineering, School of Food Engineering and Animal Science, University of São Paulo, Brazil 13635-900
}

\section{ABSTRACT}

Casein micelle stability is negatively correlated with milk concentrations of ionic calcium, which may change according to the metabolic and nutritional status of dairy cows. The present study aimed to evaluate the effect of dietary cation-anion difference (DCAD) on concentrations of casein subunits, whey proteins, ionic calcium, and milk heat and ethanol stability. Sixteen Holstein cows were distributed in 4 contemporary $4 \times$ 4 Latin square designs, which consisted of 4 periods of $21 \mathrm{~d}$ and 4 treatments according to DCAD: 290, 192, 98, and $-71 \mathrm{mEq} / \mathrm{kg}$ of dry matter (DM). The milk concentrations of ionic calcium and $\kappa$-casein were reduced as DCAD increased, whereas the milk urea nitrogen and $\beta$-lactoglobulin concentrations were increased. As a result of these alterations, the milk ethanol stability and milk stability during heating at $140^{\circ} \mathrm{C}$ were increased linearly with increasing DCAD [Y $=74.87$ (standard error $=0.87)+0.01174($ standard error $=0.0025) \times \operatorname{DCAD}(\mathrm{mEq} / \mathrm{kg}$ of $\mathrm{DM})$ and $\mathrm{Y}=$ 3.95 (standard error $=1.02)+0.01234$ (standard error $=0.0032) \times \mathrm{DCAD}(\mathrm{mEq} / \mathrm{kg}$ of $\mathrm{DM})$, respectively $]$. In addition, 3.5\% fat-corrected milk and fat, lactose, and total milk solids contents were linearly increased by $13.52,8.78,2.5$, and $2.6 \%$, respectively, according to DCAD increases from -71 to $290 \mathrm{mEq} / \mathrm{kg}$ of DM, whereas crude protein and casein content were linearly reduced by 4.83 and $4.49 \%$, respectively. In conclusion, control of metabolic changes in lactating dairy cows to maintain blood acid-base equilibrium plays an important role in keeping milk stable to ethanol and during heat treatments.

Key words: casein, dietary cation-anion difference, ionic calcium, milk ethanol stability

Received October 2, 2014.

Accepted December 6, 2014.

${ }^{1}$ Corresponding author: mveiga@usp.br

\section{INTRODUCTION}

Stability of milk proteins is an important issue in the dairy industry, especially for the manufacture of milk products that require intense heat treatments, such as UHT and powdered milk. Also, high raw milk stability is needed to avoid losses to dairy farmers due to price penalty or rejection of milk, to prevent coagulation of milk during heat treatment (Fischer et al., 2012), and also to reduce the age-related gelation of heat-treated milks during storage (García-Risco et al., 1999). Thus, the milk ethanol stability (MES) test is still used worldwide in receiving platforms of dairy plants to predict the stability of milk proteins (Fischer et al., 2012).

The casein micelle in milk is formed by casein subunits $(\alpha, \beta$, and $\kappa)$ interconnected by micellar calcium phosphate (Walstra, 1999). The calcium, besides the colloidal phase, is also present in milk in a free form (ionic calcium), which is negatively correlated with casein micelle stability (Barros et al., 1999). The increase in milk concentrations of ionic calcium (iCa) may reduce the negative charges of the casein micelles and the strength of electrostatic repulsion between them, which reduces casein resistance to form clots during contact with ethanol or during milk heat treatments (Barros et al., 1999). The $\alpha-$ and $\beta-\mathrm{CN}$ are unstable when in contact with milk iCa. However, $\kappa-\mathrm{CN}$, which is located in the outer layer of the micelle, is hydrophilic and stable to $\mathrm{iCa}$ reaction and therefore protects the micelle hydrophobic core (composed of $\alpha-$ and $\beta-\mathrm{CN}$ ) from water contact and iCa ionization (Creamer et al., 1998; Walstra, 1999). Thus, the structural arrangement of $\alpha-, \beta-$, and $\kappa_{-} \mathrm{CN}$ in the micelle, the milk concentrations of divalent cations, and the electrostatic repulsion strength between micelles may determine the heat stability (Jeurnink and De Kruif, 1995; Barros et al., 1999; Fischer et al., 2012), the formation of $\beta-L G / \kappa-C N$ complexes on heating, and, subsequently, formation of irreversible gel in UHT milk during storage (McMahon, 1995; García-Risco et al., 1999).

High incidences of unstable milk showing normal acidity values have been reported worldwide, especially in countries using UHT as the main form of fluid milk 
processing (Chavez et al., 2004; Oliveira et al., 2013). Moreover, most studies reported that the nutritional and metabolic conditions of dairy cows were the main factors that changed the milk stability (Zanela et al., 2006; Marques et al., 2011; Barbosa et al., 2012). Barbosa et al. (2012) reported that cows fed with nutrientdeficient diets produced milk with lower concentrations of $\mathrm{\kappa}-\mathrm{CN}$ and, consequently, lower ethanol stability when compared with milk from cows fed balanced diets. Alternatively, Marques et al. (2011) reported that the metabolic acidosis of dairy cows, through the action of parathyroid and 1,25-dihydroxycholecalciferol hormones, may increase milk concentrations of $\mathrm{iCa}$ and reduce the MES. Besides the $\mathrm{iCa}$ and $\kappa-\mathrm{CN}$ concentrations, other dairy components were also associated with lower milk stability, such as the formation of $\beta$-LG protein complexes with $\kappa$-CN in the micelle, MUN, temperature, $\mathrm{pH}$, and concentrations of citrate and phosphate in milk (Jeurnink and De Kruif, 1995; Singh, 2004; Lewis, 2011).

Milk constituents associated with milk stability can be changed directly by the nutrition and metabolic status of dairy cows (Marques et al., 2011; Barbosa et al., 2012; Fischer et al., 2012). However, few studies on the individual, nutritional, or metabolic factors that may alter milk protein stability exist, as both deficient and excess nutrients (through metabolic acidosis resulting from ruminal acidosis) can reduce milk stability by different means (Marques et al., 2011; Barbosa et al., 2012; Fischer et al., 2012). The use of anionic diets can be applied to study the effect of metabolic acidosis in lactating dairy cows on milk composition and stability without changing the protein and energy content of the diet (Marques et al., 2011). However, the effect of the intensity of metabolic changes of dairy cows by a gradual decrease in DCAD on heat and ethanol stability of milk has not been determined. In addition, Chavez et al. (2004) and Fischer et al. (2012) reported that the MES had limited capability to estimate milk stability during heat treatments, which limits the usefulness of results from studies based only on ethanol stability to define corrective measures of unstable, nonacid milk. Therefore, the present study aimed to evaluate the effect of DCAD of dairy cows on concentrations of milk casein subunits, whey proteins, iCa, and milk ethanol and heat stability.

\section{MATERIALS AND METHODS}

\section{Experimental Design and Animals}

At the beginning of the trial, 16 Holstein cows averaging (mean \pm SD) $22 \pm 4.5 \mathrm{~kg}$ of milk/d, $158 \pm 52$ DIM, and $618 \pm 57 \mathrm{~kg}$ of BW were distributed in 4 contem- porary $4 \times 4$ Latin squares, consisting of 4 treatments and 4 periods of $21 \mathrm{~d}$ divided into $14 \mathrm{~d}$ of adaptation and $7 \mathrm{~d}$ of sample collection. The experimental treatments consisted of 4 DCAD levels, calculated according to the $\mathrm{Na}, \mathrm{K}, \mathrm{Cl}$, and $\mathrm{S}$ concentrations of the dietetic ingredients (Table 1) as 290, 192, 98, and $-71 \mathrm{mEq} /$ $\mathrm{kg}$ of DM. The DCAD levels were calculated based on Tucker et al. (1991) using the formula: $\mathrm{mEq} / \mathrm{kg}$ of $\mathrm{DM}=[(\% \mathrm{Na}$ in $\mathrm{DM} / 0.023)+(\% \mathrm{~K}$ in $\mathrm{DM} / 0.039)]$ $-[(\% \mathrm{Cl}$ in $\mathrm{DM} / 0.0355)+(\% \mathrm{~S}$ in $\mathrm{DM} / 0.016)]$. The diets were formulated to be isoenergetic $(1.58 \mathrm{Mcal} / \mathrm{kg}$ ofDM) and to have equal amounts of protein $(160 \mathrm{~g} /$ $\mathrm{kg}$ of DM), according to NRC (2001) recommendations. Throughout the experiment, the cows were housed in individual stalls in a freestall system, fed a TMR once a day, and milked twice daily.

\section{Feed Analysis and DMI}

For determination of DMI, the amounts of feed offered and orts were weighed for each cow from d 14 to 21. The cows were fed according to DMI on the previous day, to keep daily orts of 5 to $10 \%$ of the amount offered. Samples of the feed supplied and orts were collected during the last $4 \mathrm{~d}$ of each experimental period, and were stored at $-20^{\circ} \mathrm{C}$, to compose a sample by period for each animal based on the dry weight for chemical analysis. The DM, ash, CP, and ether extract (EE) content in samples of feed and orts were determined according to AOAC International (1995). Acid detergent insoluble CP (ADICP), neutral detergent insoluble $\mathrm{CP}$ (NDICP), ADL, NDF, and ADF contents were obtained according to Van Soest et al. (1991). The NDF analysis was performed according to adaptations described by Mertens (2002) using $\alpha$-amylase without sodium sulfite. The samples were ground, dry digested, and solubilized before mineral analysis. The $\mathrm{Ca}, \mathrm{P}, \mathrm{Na}$, and $\mathrm{K}$ content were determined by flame emission spectrophotometer (Thermo Fisher Scientific, 2008), and chloride content was determined according to the Mohr method (AOAC International, 1995). The S concentration was obtained by colorimetry (molybdenum blue) according to methodology described by Malavolta et al. (1997). The NFC content was calculated according to Hall (2000) and the TDN and $\mathrm{NE}_{\mathrm{L}}$ were calculated according to NRC (2001). The DMI and ingested amounts of CP, NDF, EE, NFC, TDN, Ca, P, Na, K, Cl, and S were calculated based on the chemical composition of feed and orts and according to NRC (2001).

\section{Milk Sampling and Analysis}

Milk yield was measured daily and the value was used to calculate the $3.5 \%$ FCM according to Sklan et 
Table 1. Ingredient proportion and chemical composition of diets of dairy cows according to DCAD

\begin{tabular}{|c|c|c|c|c|}
\hline \multirow[b]{2}{*}{ Item } & \multicolumn{4}{|c|}{$\mathrm{DCAD}, \mathrm{mEq} / \mathrm{kg}$ of $\mathrm{DM}$} \\
\hline & -71 & 98 & 192 & 290 \\
\hline \multicolumn{5}{|l|}{ Ingredient, $\mathrm{g} / \mathrm{kg}$ of $\mathrm{DM}$} \\
\hline Maize silage & 600 & 600 & 600 & 600 \\
\hline Ground corn & 205.63 & 212.38 & 214.32 & 209.72 \\
\hline $46 \%$ CP soybean meal & 153.45 & 146.47 & 145.78 & 150.23 \\
\hline Mineral mixture $^{1}$ & 15.34 & 15.34 & 15.34 & 15.34 \\
\hline $\mathrm{NaCl}$ & 5.11 & 7.67 & 7.93 & - \\
\hline Sodium bicarbonate & - & 2.25 & 3.58 & 11.66 \\
\hline Ammonium sulfate & 14.83 & 5.68 & - & - \\
\hline Urea & 2.56 & 7.16 & 9.97 & 9.97 \\
\hline Dicalcium phosphate & 2.56 & 2.56 & 2.56 & 2.56 \\
\hline Magnesium oxide & 0.56 & 0.56 & 0.56 & 0.56 \\
\hline \multicolumn{5}{|l|}{$\begin{array}{l}\text { Chemical composition, } \mathrm{g} / \mathrm{kg} \text { of } \mathrm{DM} \\
\text { (unless otherwise noted) }\end{array}$} \\
\hline $\mathrm{DM}, \mathrm{g} / \mathrm{kg}$ of natural matter & 609 & 609 & 608.9 & 608.9 \\
\hline $\mathrm{OM}$ & 918.60 & 918.70 & 919.90 & 919.60 \\
\hline $\mathrm{CP}$ & 163.17 & 161.13 & 161.13 & 163.07 \\
\hline Ether extract & 27.70 & 27.90 & 27.98 & 27.80 \\
\hline $\mathrm{TDN}^{2}$ & 665.17 & 670.56 & 674.33 & 677.00 \\
\hline $\mathrm{NE}_{\mathrm{L},}^{2} \mathrm{Mcal} / \mathrm{kg}$ of $\mathrm{DM}$ & 1.51 & 1.52 & 1.53 & 1.54 \\
\hline $\mathrm{NDF}$ & 351.41 & 350.90 & 350.90 & 351.41 \\
\hline $\mathrm{NDFap}^{3}$ & 321.65 & 321.87 & 321.91 & 321.97 \\
\hline $\mathrm{ADF}$ & 190.70 & 190.10 & 190.10 & 190.50 \\
\hline Neutral detergent insoluble CP & 29.76 & 29.02 & 28.98 & 29.44 \\
\hline Acid detergent insoluble CP & 11.77 & 11.74 & 11.76 & 11.77 \\
\hline $\mathrm{NFC}^{4}$ & 401.59 & 409.73 & 414.18 & 417.40 \\
\hline ADL & 21.30 & 21.20 & 21.20 & 21.30 \\
\hline Ash & 6.54 & 6.51 & 6.39 & 5.84 \\
\hline $\mathrm{Ca}$ & 6.14 & 6.14 & 6.14 & 6.14 \\
\hline $\mathrm{P}$ & 3.15 & 3.13 & 3.13 & 3.07 \\
\hline $\mathrm{Na}$ & 3.38 & 4.96 & 5.42 & 4.65 \\
\hline $\mathrm{K}$ & 10.23 & 10.08 & 10.08 & 10.13 \\
\hline $\mathrm{Cl}$ & 3.89 & 5.12 & 5.52 & 0.87 \\
\hline $\mathrm{S}$ & 5.93 & 3.71 & 2.35 & 2.35 \\
\hline \multicolumn{5}{|c|}{$\begin{array}{l}{ }^{1} \text { Mineral mixture composition per kilogram: } 242 \mathrm{~g} \text { of } \mathrm{Ca}[\operatorname{minimum}(\mathrm{min})], 30 \mathrm{mg} \text { of } \mathrm{Co}(\mathrm{min}), 1,008 \mathrm{mg} \text { of } \\
(\mathrm{min}), 80 \mathrm{~g} \text { of } \mathrm{S}(\mathrm{min}), 390 \mathrm{mg} \text { of } \mathrm{Fl}(\mathrm{max}), 39 \mathrm{~g} \text { of } \mathrm{P}(\mathrm{min}), 60 \mathrm{mg} \text { of } \mathrm{I}(\mathrm{min}), 20 \mathrm{~g} \text { of } \mathrm{Mg}(\mathrm{min}), 2,998 \mathrm{mg} \\
\mathrm{Mn}(\mathrm{min}), 1,100 \mathrm{mg} \text { of monensin sodium }(\mathrm{min}), 30 \mathrm{mg} \text { of } \mathrm{Se}(\mathrm{min}), 4,032 \mathrm{mg} \text { of } \mathrm{Zn}(\mathrm{min}), 400,000 \mathrm{IU} \text { of vitar } \\
\mathrm{A}(\mathrm{min}), 40,000 \mathrm{IU} \text { of vitamin } \mathrm{D}_{3}(\mathrm{~min}) \text {, and } 1,450 \mathrm{IU} \text { of vitamin } \mathrm{E}(\mathrm{min}) . \\
{ }^{2} \text { Estimate by NRC (2001). } \\
{ }^{3} \mathrm{NDFap}=\text { neutral detergent fiber corrected to ash and protein. }\end{array}$} \\
\hline
\end{tabular}

al. (1994). Milk samples were collected from d 15 to 16 of each period, chilled, and preserved with 2-bromo2-nitropropane-1,3-diol $(0.05 \%, \mathrm{wt} / \mathrm{vol})$ for determination of fat, lactose, TS, casein, and CP by infrared absorption (Bentley Instruments, 1995) and milk freezing point by Fourier transform infrared spectroscopy (Foss Analytical, 2008). Milk SNF was obtained by the difference between fat and TS content. The MUN content was determined by an enzymatic and colorimetric methodology (Bentley Instruments, 1998).

In each experimental period, milk samples were collected for immediate determination of iCa concentration using a potentiometer with selective electrode and pH by potentiometry (Barros et al., 1999). Individual milk samples from all cows were collected and frozen at $-20^{\circ} \mathrm{C}$ for analysis of $\mathrm{Ca}, \mathrm{P}, \mathrm{Na}$, and $\mathrm{K}$ by flame emission spectrophotometer (Thermo Fisher Scientific, 2008), and the chloride $(\mathrm{Cl})$ content was determined according to the Mohr method (AOAC International, 1995).

Composite milk samples from 2 daily milkings were collected and stored for $12 \mathrm{~h}$ at $5^{\circ} \mathrm{C}$ before the determination of MES at the following concentrations ( $\mathrm{vol} / \mathrm{vol}$ ): $68,70,72,74,76,78$, and $80 \%$ ethanol (Zanela et al., 2006). Results were expressed by the lowest concentration of alcohol in which coagulation occurred. In addition, milk heat stability was assessed by determination of coagulation time as follows: glass capillaries $(7.00 \mathrm{~cm}$ long, $0.15 \mathrm{~cm}$ external diameter, and $0.1 \mathrm{~cm}$ internal diameter) were individually filled with milk samples, heat sealed, and submitted to immersion in glycerin to heating at $140^{\circ} \mathrm{C}$. The time taken for the milk samples 
to clot was recorded from the capillary introduction in the glycerin bath at $140^{\circ} \mathrm{C}$ until the appearance of the first visible signs of coagulation (Negri et al., 2003).

Representative milk samples from 2 daily milkings were collected and frozen $\left(-20^{\circ} \mathrm{C}\right)$ until analysis of the milk caseins subunits $(\alpha, \beta$, and $\kappa)$ and whey proteins $(\alpha-\mathrm{LA}$ and $\beta$-LG) concentration. Each sample was evaluated in duplicate by HPLC according to the methodology proposed by Bobe et al. (1998). Separation and identification of the proteins were performed at $220 \mathrm{~nm}$ in a HPLC system (Shimadzu, Kyoto, Japan) equipped with UV detector and Jupiter C18 column $(4 \mu \mathrm{m}, 4.6$ $\times 150 \mathrm{~mm}$; Phenomenex, Torrance, CA). Chromatographic run was carried out at room temperature using mobile phases solvent A (acetonitrile:water:trifluoroac etic acid, 100:900:1) and solvent B (acetonitrile:water: trifluoroacetic acid; 900:100:1). The gradient program started with $25 \%$ solvent $\mathrm{B}$, and the proportion of the solvent was gradually increased after the injection of the sample [34 (4), 48 (11), 50 (13), and 10\% (17 min)] and returned to the initial conditions after 2 min. Flow rate was adjusted at $1.0 \mathrm{~mL} / \mathrm{min}$ (Oliveira et al., 2013). Retention times for $\alpha_{S^{-}}, \beta$-, and $\kappa-\mathrm{CN}, \alpha-\mathrm{LA}$, and $\beta-\mathrm{LG}$, respectively, were $12.3,12.9,9.1,14.4$, and $14.1 \mathrm{~min}$.

Quantification of casein fractions $\left(\alpha_{S 1}, \alpha_{S 2}, \beta\right.$, and $\left.\kappa\right)$ and whey proteins was performed by measuring peak areas of the samples and then plotting them against the calibration curves of each casein fraction. Purified $\alpha_{S^{-}}, \beta-$, and $\kappa-\mathrm{CN}, \alpha-\mathrm{La}$, and $\beta-\mathrm{LG}$ standards (Sigma, St. Louis, MO) were diluted in distilled water, and aliquots were frozen at $-20^{\circ} \mathrm{C}$. Individual protein standards were prepared in the same way described for milk samples, at the following concentrations: $\alpha_{S^{-}} \mathrm{CN}$ : 0.5 , $1.0,2.0$, and $4.0 \mathrm{mg} / \mathrm{mL} ; \beta-\mathrm{CN}: 0.375,0.75,1.50$, and $3.0 \mathrm{mg} / \mathrm{mL} ; \kappa-\mathrm{CN}: 0.187,0.375,0.75$, and $1.50 \mathrm{mg} / \mathrm{mL}$; $\alpha$-LA: $0.125,0.250,0.375$, and $0.5 \mathrm{mg} / \mathrm{mL} ; \beta$-LG: 0.25 , $0.5,0.75$ and $1.0 \mathrm{mg} / \mathrm{mL}$. The $\alpha_{\mathrm{S}_{1}}: \mathrm{\alpha}_{\mathrm{S} 2}-\mathrm{CN}$ ratio was assumed to be 4:1 (wt/wt; Bobe et al., 1998).

\section{Statistical Analysis}

The data were analyzed using SAS (version 9.2, SAS Institute Inc., Cary, NC) after testing for residual normality and homogeneity of variance. The data were analyzed using the MIXED procedure of SAS according to the following model:

$$
\mathrm{Y}_{\mathrm{ijkl}}=\mu+\mathrm{T}_{\mathrm{i}}+\mathrm{S}_{\mathrm{j}}+\mathrm{C}_{\mathrm{k}(\mathrm{j})}+\mathrm{P}_{1}+\mathrm{e}_{\mathrm{ijkl}},
$$

where $Y_{\mathrm{ijkl}}=$ dependent variable; $\mu=$ overall mean; $T_{\mathrm{i}}$ $=$ fixed effect of treatment $\mathrm{i}(3 \mathrm{df}) ; \mathrm{S}_{\mathrm{j}}=$ fixed effect of Latin square $\mathrm{j}$ [1 to $4(3 \mathrm{df})$ ]; $\mathrm{C}_{\mathrm{k}(\mathrm{j})}=$ random effect of cow $\mathrm{k}$ within each Latin square $[\mathrm{k}=1$ to $16(12 \mathrm{df})] ; \mathrm{P}_{1}$
$=$ fixed effect of period $\mathrm{l}[1$ to $4(3 \mathrm{df})] ; \mathrm{e}_{\mathrm{ijkl}}=$ random error associated to each observation.

The orthogonal polynomials coefficients were obtained using the IML procedure of SAS because the treatments were not equally spaced. The treatment effect was decomposed into 3 orthogonal polynomial contrasts (linear, quadratic, and deviation). Intercepts and slopes were calculated using the estimate option of the MIXED procedure of SAS. In addition, Pearson correlation was used to evaluate the association between heat and ethanol milk stability. For all statistical analyses, significance was declared at $P \leq 0.05$ and trends at $P \leq 0.10$.

\section{RESULTS}

In the present study, the DMI increased in a quadratic $(P<0.0001)$ form with increasing DCAD. According to the equation $[\mathrm{Y}=22.63(\mathrm{SE}=0.94)+0.0185(\mathrm{SE}$ $=0.0032) \times \mathrm{DCAD}(\mathrm{mEq} / \mathrm{kg}$ of $\mathrm{DM})-0.00008(\mathrm{SE}=$ $0.000013) \times \operatorname{DCAD}^{2}\left(\mathrm{mEq} / \mathrm{kg}\right.$ of $\left.\left.\mathrm{DM}^{2}\right)\right]$, the DMI peak was obtained with DCAD of $115.62 \mathrm{mEq} / \mathrm{kg}$ of DM, where the DMI estimate was $23.70 \mathrm{~kg} / \mathrm{d}$. Similar to DMI, ingestion of $\mathrm{CP}, \mathrm{NDF}, \mathrm{EE}, \mathrm{Ca}, \mathrm{P}, \mathrm{Na}$, and $\mathrm{K}$ were also increased in a quadratic form as DCAD increased. The maximum nutrient intake (CP, NDF, EE, Ca, P, $\mathrm{Na}$, and $\mathrm{K}$ ) was observed when DCAD was between 100 and $150 \mathrm{mEq} / \mathrm{kg}$ of $\mathrm{DM}$, where the maximum consumption of CP and NDF was obtained with DCAD of 125 and $118.33 \mathrm{mEq} / \mathrm{kg}$ of DM, respectively (Table 2).

Changes of DMI and metabolic status of dairy cows may alter milk yield and composition. In the current study, milk yield (MY) and FCM were increased in the quadratic $(P=0.020)$ and linear $(P<0.0001)$ form, respectively, according to the increase of DCAD. The point of maximum milk yield $(22.35 \mathrm{~kg} / \mathrm{d})$ was obtained with DCAD of $171.67 \mathrm{mEq} / \mathrm{kg}$ of DM [Y $=21.47$ (SE $=1.22)+0.0103(\mathrm{SE}=0.0038) \times \operatorname{DCAD}(\mathrm{mEq} / \mathrm{kg}$ of $\mathrm{DM})-0.00003(\mathrm{SE}=0.000012) \times \mathrm{DCAD}^{2}(\mathrm{mEq} /$ $\mathrm{kg}$ of $\left.\mathrm{DM}^{2}\right)$. By increasing the DCAD from -71 to $290 \mathrm{mEq} / \mathrm{kg}$ of DM, the FCM increased $2.9 \mathrm{~kg} / \mathrm{d}[\mathrm{Y}=$ $22.23(\mathrm{SE}=1.19)+0.008798(\mathrm{SE}=0.0016) \times \mathrm{DCAD}$ $(\mathrm{mEq} / \mathrm{kg}$ of $\mathrm{DM})]$. Conversely, productive efficiency $(\mathrm{MY} / \mathrm{DMI})$ was reduced in a quadratic $(P=0.004)$ form with increasing DCAD. Milk concentrations of fat, lactose, TS, and MUN increased linearly with increasing DCAD, whereas milk content of SNF increased in a quadratic form. According to the increase of DCAD from -71 to $290 \mathrm{mEq} / \mathrm{kg}$ of $\mathrm{DM}$, the milk fat content was $8.71 \%$ higher $[\mathrm{Y}=3.82(\mathrm{SE}=0.15)+0.0008(\mathrm{SE}$ $=0,0003) \times \mathrm{DCAD}(\mathrm{mEq} / \mathrm{kg}$ of $\mathrm{DM})]$. In contrast, the milk content of $\mathrm{CP}$ and casein decreased linearly $(P=$ 0.004 and $P=0.039$, respectively) as DCAD increased. 
Table 2. Effect of DCAD of dairy cows on dry matter and nutrients intake

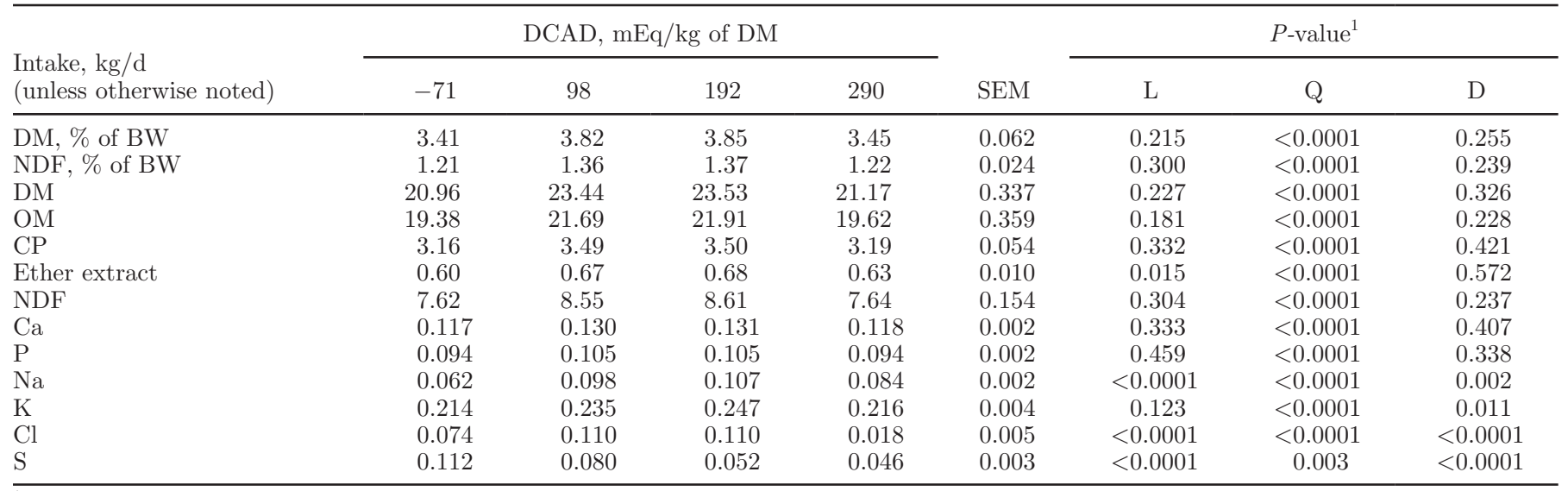

${ }^{1} \mathrm{~L}=$ probability of linear effect, $\mathrm{Q}=$ probability of quadratic effect, $\mathrm{D}=$ deviation.

As a result of the effects of DCAD on milk yield and composition, the daily production of milk components was also modified by the DCAD levels studied. An increase in milk fat production was observed in a linear $(P=0.0003)$ form according to increase of DCAD, whereas $\mathrm{CP}$, casein, lactose, SNF, and TS production increased in a quadratic form (Table 3). In response to the increased milk production, the point of maximum daily milk TS production was achieved when the DCAD was $170.21 \mathrm{mEq} / \mathrm{kg}$ of DM. However, the point of maximum production of $\mathrm{CP}$ and casein were reached when the DCAD was 118.57 and $130 \mathrm{mEq} / \mathrm{kg}$ of DM, respectively.

In the present study, no effect of DCAD was noted on concentrations of $\alpha-\left({ }_{\mathrm{S} 1}\right.$ and $\left.\mathrm{S}_{\mathrm{S}}\right)$ and $\beta-\mathrm{CN}$ and $\alpha-\mathrm{LA}$.
However, milk content of $\kappa$-CN decreased linearly $(P=$ 0.031 ) with increasing DCAD, whereas milk content of $\beta$-LG increased in a linear $(P=0.002)$ form. Therefore, when the DCAD increased from -71 to $290 \mathrm{mEq} / \mathrm{kg}$ of DM, the milk $\kappa$-CN concentration reduced $7.69 \%$, whereas the $\beta$-LG level increased $17.14 \%$. However, a tendency $(P=0.089)$ was noted for a linear reduction in the proportion of $\kappa-\mathrm{CN}$ in total $\mathrm{CP}$ as DCAD increased. The concentration of $\beta$-LG linearly $(P=$ 0.006 ) increased in $0.79 \mathrm{~g} / 100 \mathrm{~g}$ of $\mathrm{CP}$ according to an increase in the DCAD from -71 to $290 \mathrm{mEq} / \mathrm{kg}$ of DM (Table 4).

The mineral composition of milk was affected by DCAD, as the milk concentrations of $\mathrm{iCa}$ and chloride increased in a quadratic $(P=0.009)$ and linear $(P=$

Table 3. Effect of DCAD of dairy cows on milk yield and composition

\begin{tabular}{|c|c|c|c|c|c|c|c|c|}
\hline \multirow[b]{2}{*}{ Item } & \multicolumn{4}{|c|}{$\mathrm{DCAD}, \mathrm{mEq} / \mathrm{kg}$ of $\mathrm{DM}$} & \multirow[b]{2}{*}{ SEM } & \multicolumn{3}{|c|}{$P$-value ${ }^{1}$} \\
\hline & -71 & 98 & 192 & 290 & & $\mathrm{~L}$ & $\mathrm{Q}$ & $\mathrm{D}$ \\
\hline Milk yield, $\mathrm{kg} / \mathrm{d}$ & 20.71 & 22.17 & 22.66 & 22.05 & 0.599 & 0.004 & 0.020 & 0.520 \\
\hline $\mathrm{FCM}, \mathrm{kg} / \mathrm{d}$ & 21.42 & 23.32 & 24.49 & 24.32 & 0.611 & $<0.0001$ & 0.127 & 0.367 \\
\hline Fat, $\mathrm{kg} / \mathrm{d}$ & 0.76 & 0.84 & 0.88 & 0.87 & 0.022 & 0.001 & 0.095 & 0.434 \\
\hline $\mathrm{CP}, \mathrm{kg} / \mathrm{d}$ & 0.66 & 0.69 & 0.72 & 0.66 & 0.012 & 0.509 & 0.017 & 0.213 \\
\hline Casein, kg/d & 0.49 & 0.51 & 0.53 & 0.48 & 0.009 & 0.612 & 0.008 & 0.120 \\
\hline Lactose, $\mathrm{kg} / \mathrm{d}$ & 0.89 & 0.97 & 0.99 & 0.97 & 0.027 & 0.001 & 0.001 & 0.514 \\
\hline $\mathrm{SNF}, \mathrm{kg} / \mathrm{d}$ & 1.73 & 1.88 & 1.91 & 1.82 & 0.042 & 0.011 & 0.002 & 0.455 \\
\hline $\mathrm{TS}, \mathrm{kg} / \mathrm{d}$ & 2.51 & 2.72 & 2.80 & 2.69 & 0.061 & 0.002 & 0.008 & 0.396 \\
\hline Fat, g/100 g & 3.76 & 3.86 & 4.00 & 4.09 & 0.071 & 0.001 & 0.661 & 0.644 \\
\hline $\mathrm{CP}, \mathrm{g} / 100 \mathrm{~g}$ & 3.31 & 3.25 & 3.26 & 3.15 & 0.052 & 0.004 & 0.352 & 0.219 \\
\hline Casein, g/100 g & 2.45 & 2.39 & 2.42 & 2.34 & 0.046 & 0.039 & 0.586 & 0.177 \\
\hline Casein, $\%$ CP & 73.95 & 73.73 & 74.14 & 73.30 & 0.370 & 0.242 & 0.296 & 0.121 \\
\hline MUN, mg/dL & 17.71 & 19.07 & 18.90 & 21.43 & 0.522 & 0.002 & 0.264 & 0.241 \\
\hline Lactose, $\mathrm{g} / 100 \mathrm{~g}$ & 4.32 & 4.39 & 4.42 & 4.43 & 0.047 & $<0.0001$ & 0.340 & 0.902 \\
\hline $\mathrm{SNF}, \mathrm{g} / 100 \mathrm{~g}$ & 8.55 & 8.58 & 8.64 & 8.53 & 0.063 & 0.909 & 0.182 & 0.191 \\
\hline $\mathrm{TS}, \mathrm{g} / 100 \mathrm{~g}$ & 12.32 & 12.44 & 12.64 & 12.64 & 0.120 & 0.005 & 0.857 & 0.313 \\
\hline $\mathrm{BW}, \mathrm{kg}$ & 617 & 617.5 & 620.44 & 615.94 & 57.540 & 0.977 & 0.646 & 0.581 \\
\hline Productive efficiency (milk yield/DMI) & 1.04 & 0.98 & 0.99 & 1.03 & 0.034 & 0.675 & 0.004 & 0.911 \\
\hline
\end{tabular}

${ }^{1} \mathrm{~L}=$ probability of linear effect, $\mathrm{Q}=$ probability of quadratic effect, $\mathrm{D}=$ deviation. 
Table 4. Effect of DCAD of dairy cows on caseins subunits and whey proteins

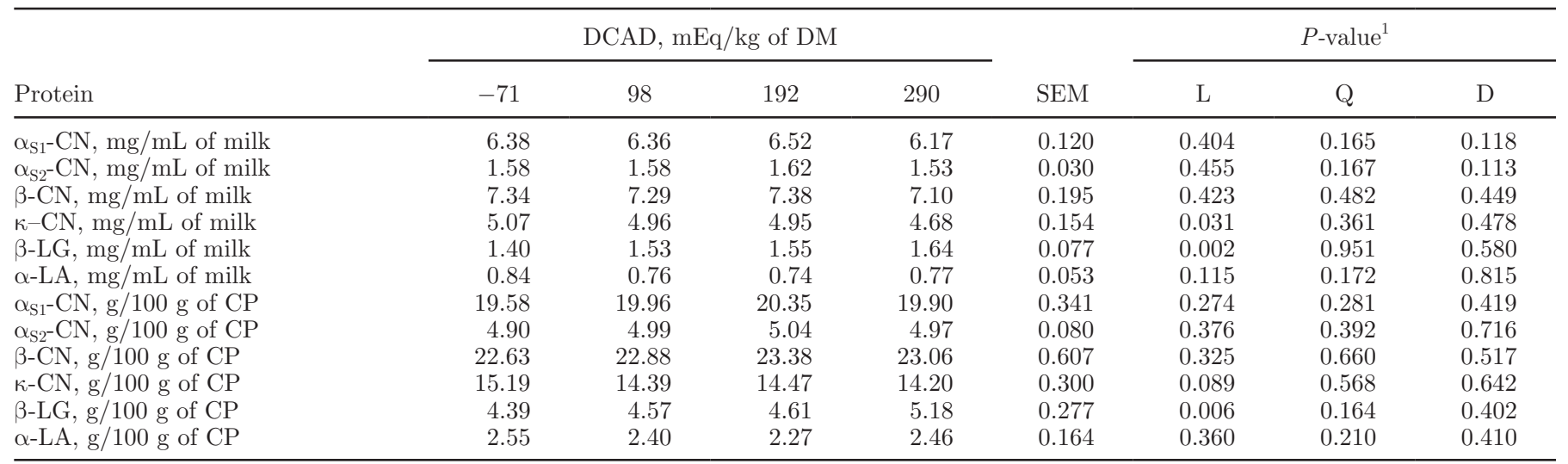

${ }^{1} \mathrm{~L}=$ probability of linear effect, $\mathrm{Q}=$ probability of quadratic effect, $\mathrm{D}=$ deviation.

0.014) form, respectively, by reducing the DCAD. The lowest milk concentrations of iCa were obtained when DCAD was $169 \mathrm{mEq} / \mathrm{kg}$ of DM. In addition, the reduction of DCAD tended $(P=0.070)$ to linearly increase the $\mathrm{K}$ concentration and, in a quadratic form $(P=$ 0.096), the Na concentration in the milk. However, the daily production $(\mathrm{kg} / \mathrm{d}$ per cow) of $\mathrm{P}, \mathrm{Na}, \mathrm{K}$, and $\mathrm{Cl}$ was not affected by DCAD (Table 5).

In addition to changing the performance of lactating dairy cows, the DCAD may alter the resistance of milk proteins to form clots during the ethanol reaction or during heat treatment. In the present study, the milk ethanol and heat stability linearly $(P<0.0001$ and $P=0.0005$, respectively) decreased according to the DCAD reduction (Table 6). By reducing the DCAD, from 290 to $-71 \mathrm{mEq} / \mathrm{kg}$ of $\mathrm{DM}$, the resistance of milk to form clots during heating at $140^{\circ} \mathrm{C}$ was reduced by 4.77 min. Similarly, by reducing the DCAD, the ethanol concentration required in the alcohol solution was reduced by $4.6 \%$ to cause milk precipitation (Figure 1). The milk freezing point and $\mathrm{pH}$ of milk were not altered by DCAD. In addition, we observed medium ( $\mathrm{r}$ $=0.45)$ significant $(P=0.01)$ correlation between heat and ethanol stability.

\section{DISCUSSION}

\section{DMI and Milk Yield}

In the present study, the DM and nutrients (CP, $\mathrm{NDF}, \mathrm{EE}, \mathrm{Ca}, \mathrm{P}, \mathrm{Na}$, and $\mathrm{K}$ ) intake increased in a quadratic form with increasing DCAD $(P<0.0001)$. Similar results were reported by $\mathrm{Hu}$ and Murphy (2004), who conducted a meta-analysis and found that increasing DCAD levels quadratically elevated the DMI of dairy cows (maximum intake observed when DCAD was $395.52 \mathrm{mEq} / \mathrm{kg}$ of $\mathrm{DM})$. However, $\mathrm{Hu}$ and Murphy (2004) did not include S in the DCAD calculation and used the following formula: $\mathrm{DCAD}=\mathrm{Na}+\mathrm{K}-$ Cl. This difference of the calculation methodology of DCAD may affect the optimal DCAD recommended for lactating dairy cows when compared with other studies

Table 5. Effect of DCAD of dairy cows on mineral milk content and daily secretion

\begin{tabular}{|c|c|c|c|c|c|c|c|c|}
\hline \multirow{2}{*}{$\begin{array}{l}\text { Minerals, g/100 g } \\
\text { (unless otherwise noted) }\end{array}$} & \multicolumn{4}{|c|}{$\mathrm{DCAD}, \mathrm{mEq} / \mathrm{kg}$ of $\mathrm{DM}$} & \multirow[b]{2}{*}{ SEM } & \multicolumn{3}{|c|}{$P$-value ${ }^{1}$} \\
\hline & -71 & 98 & 192 & 290 & & $\mathrm{~L}$ & $\mathrm{Q}$ & $\mathrm{D}$ \\
\hline \multicolumn{9}{|l|}{ Milk content } \\
\hline $\mathrm{iCa}, \mathrm{mg} / \mathrm{L}$ & 92.34 & 80.10 & 78.61 & 82.17 & 1.984 & 0.002 & 0.009 & 0.914 \\
\hline $\mathrm{K}$ & 0.101 & 0.101 & 0.095 & 0.092 & 0.003 & 0.070 & 0.544 & 0.478 \\
\hline $\mathrm{Na}$ & 0.074 & 0.070 & 0.069 & 0.074 & 0.002 & 0.757 & 0.096 & 0.599 \\
\hline $\mathrm{Cl}$ & 0.130 & 0.116 & 0.118 & 0.117 & 0.003 & 0.014 & 0.101 & 0.319 \\
\hline $\mathrm{K}$ & 0.020 & 0.024 & 0.022 & 0.020 & 0.001 & 0.942 & 0.080 & 0.452 \\
\hline $\mathrm{Na}$ & 0.015 & 0.015 & 0.015 & 0.016 & 0.000 & 0.327 & 0.770 & 0.646 \\
\hline $\mathrm{Cl}$ & 0.026 & 0.026 & 0.027 & 0.025 & 0.001 & 0.770 & 0.326 & 0.231 \\
\hline $\mathrm{P}$ & 0.017 & 0.016 & 0.017 & 0.016 & 0.001 & 0.337 & 0.517 & 0.084 \\
\hline
\end{tabular}

${ }^{1} \mathrm{~L}=$ probability of linear effect, $\mathrm{Q}=$ probability of quadratic effect, $\mathrm{D}=$ deviation. 
Table 6. Effect of DCAD of dairy cows on milk ethanol and heat stability

\begin{tabular}{|c|c|c|c|c|c|c|c|c|}
\hline Item & \multicolumn{4}{|c|}{$\mathrm{DCAD}, \mathrm{mEq} / \mathrm{kg}$ of $\mathrm{DM}$} & SEM & \multicolumn{3}{|c|}{$P$-value ${ }^{1}$} \\
\hline Milk ethanol stability, ${ }^{2} \%$ & 73.42 & 76.61 & 76.40 & 78.02 & 0.560 & $<0.0001$ & 0.468 & 0.251 \\
\hline $\mathrm{pH}$ & 6.73 & 6.75 & 6.70 & 6.80 & 0.021 & 0.130 & 0.080 & 0.060 \\
\hline Cryoscopy, ${ }^{\circ} \mathrm{H}$ & -0.535 & -0.537 & -0.539 & -0.533 & 0.002 & 0.880 & 0.066 & 0.385 \\
\hline
\end{tabular}

${ }^{1} \mathrm{~L}=$ probability of linear effect, $\mathrm{Q}=$ probability of quadratic effect, $\mathrm{D}=$ deviation.

${ }^{2}$ Milk ethanol stability $=$ minimum concentration of ethanol in the alcohol solution $(\mathrm{vol} / \mathrm{vol})$ necessary for precipitation; coagulation time $=$ necessary time for milk precipitation at $140^{\circ} \mathrm{C}$. Correlation between milk ethanol stability and coagulation time: $\mathrm{r}=0.45(P<0.01)$.

that included S in the calculation. Delaquis and Block (1995) studied cows in the middle stage of lactation and reported increased DMI from 15.6 to $17.0 \mathrm{~kg} / \mathrm{d}$ when the DCAD increased from 140.2 to $372.7 \mathrm{mEq} /$ $\mathrm{kg}$ of DM. The lower DMI observed by reducing the DCAD, particularly in diets with a negative DCAD, may be associated with the addition of anionic salts, such as ammonium sulfate used in our study. Anionic salts (usually sodium chloride and sulfur sources) have low acceptance by cows and can therefore reduce the DMI (West et al., 1991). The DMI may also be reduced by decreasing the DCAD in response to metabolic acidosis, by reducing serum concentrations of bicarbonate (Sharif et al., 2010). Changes in rumen microbial activity due to the reduction of DCAD were also associated with the DMI decrease. To reduce the DCAD, the replacement of sodium bicarbonate by anionic salts may reduce ruminal $\mathrm{pH}$, and therefore decrease the optimum conditions for the activity of cellulolytic bacteria and reduce the rate of NDF digestion, the rate of passage through total gastrointestinal tract, and, consequently, the DMI (Sharif et al., 2010).

Changes of DMI, ruminal fermentation, and blood ionic balance are factors that can directly affect the flow of nutrients to the mammary gland and thus the MY (Hu and Murphy, 2004; Sharif et al., 2010). In our study, the MY increased in a quadratic form as DCAD increased. Similarly, Hu and Murphy (2004) also reported that the increase of DCAD increased the MY in a quadratic form and that the DCAD of $490 \mathrm{mEq} /$ $\mathrm{kg}$ of DM was the optimum level for FCM (4\% of fat). Similar results were described by West et al. (1991) and Delaquis and Block (1995), who reported a positive association between MY and DCAD. Alternately, Roche et al. (2005) studied the effects of high DCAD of early lactation dairy cows grazing pasture and reported no effect of increasing DCAD (from 230 to $880 \mathrm{mEq}$ / $\mathrm{kg}$ of DM) on DMI and MY. In the present study, MY increased in response to the DCAD increase (from -71 to $290 \mathrm{mEq} / \mathrm{kg}$ of DM) probably due to the higher DM and nutrient intake. In response to the higher consumption, the availability of nutrients to ruminal fermenta- tion and intestinal absorption may be increased, which may result in a higher flow of nutrients to the mammary gland to be used in milk synthesis. In addition, with the increasing DCAD, available acids in the bloodstream can be neutralized by increasing the concentration of current $\mathrm{HCO}_{3}$, which facilitates the entry of glucose into cells due to high insulin activity. With the higher uptake of glucose into cells, the lactose synthesis in the mammary gland may be increased, which may contribute to the rise of MY by osmotic pressure exerted by lactose in the milk synthesis (Block, 1994; Hu and Murphy, 2004; Sharif et al., 2010).

\section{Milk Composition and Stability}

Fat content is an important component for dairy processing yield and may vary according to the diet, especially when changes occur in rumen microbial activity. In our study, the fat content of milk increased linearly with increasing DCAD. Similar results were reported by Delaquis and Block (1995), Roche et al. (2005), and Apper-Bossard et al. (2010), who reported higher fat content in milk when cows were fed increasing DCAD. This increased fat content of milk may be a response to the positive effect of DCAD on rumen $\mathrm{pH}$ after feeding (Apper-Bossard et al., 2010), which may result in a more stable rumen microbial activity, especially of cellulolytic bacteria that present great growth at around neutral pH (Allen, 1997). Thus, with proper conditions for ruminal microbial activity, the biohydrogenation process of unsaturated FA can be higher than when the ruminal $\mathrm{pH}$ is lowered by decreasing the formation of intermediate FA (trans), which are negatively associated with the synthesis of fat in the mammary gland (Bauman and Griinari, 2003). Additionally, Roche et al. (2005) reported that increasing DCAD might increase DMI as well as short-chain FA synthesis in the rumen, providing more substrate for de novo FA production, which may contribute to increase the milk fat content.

Lactose is an important osmoregulator of MY, and the milk content of lactose is less influenced by nutritional factors when compared with other milk compo- 

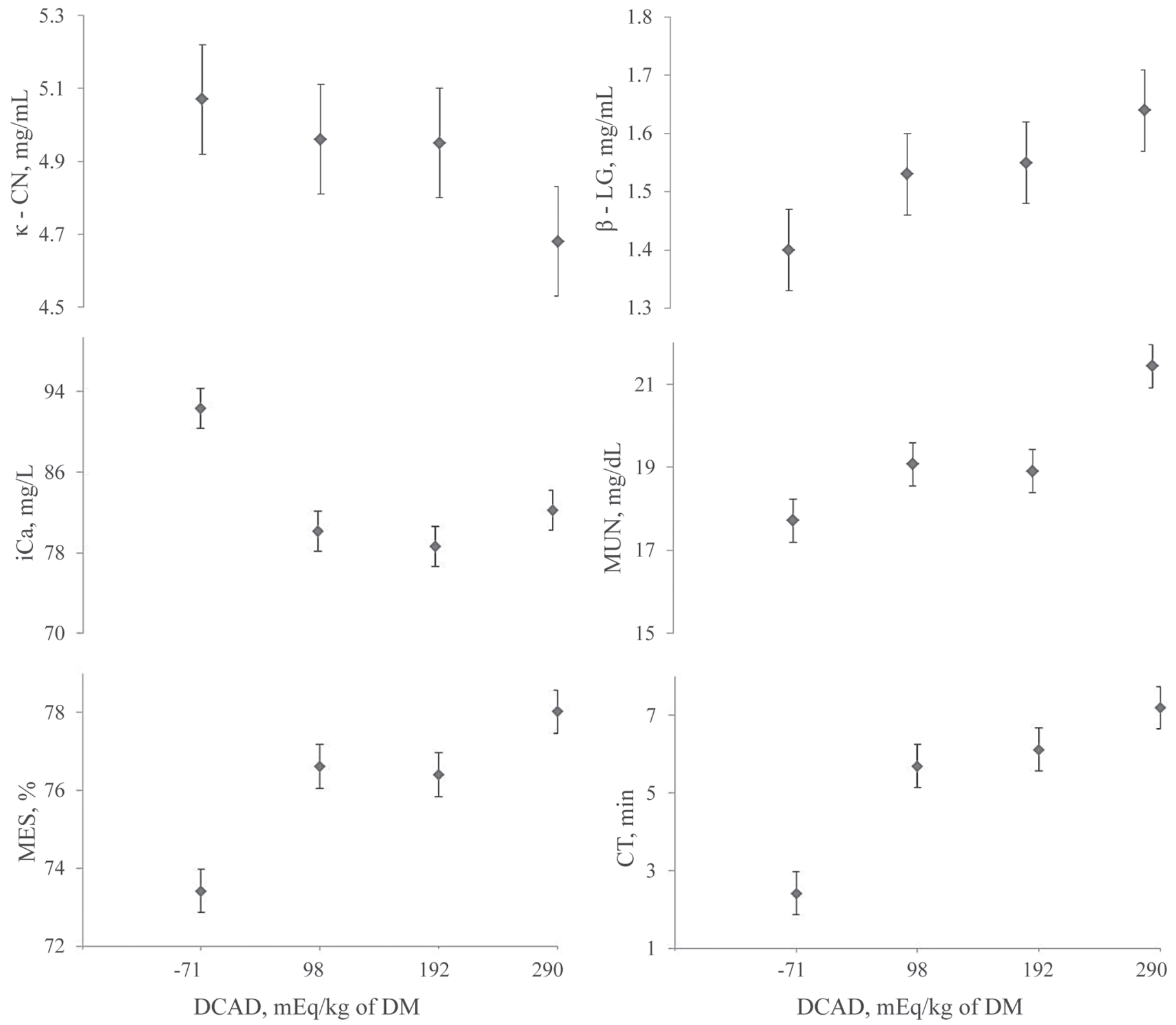

Figure 1. Effect of DCAD $(\mathrm{mEq} / \mathrm{kg}$ of $\mathrm{DM})$ on concentrations of $\mathrm{k}-\mathrm{CN}[\mathrm{Y}=5.02(\mathrm{SE}=0.30)-0.00098(\mathrm{SE}=0.0004) \times \mathrm{DCAD}(\mathrm{mEq} / \mathrm{kg}$ of $\mathrm{DM})], \beta-\mathrm{LG}[\mathrm{Y}=1.46(\mathrm{SE}=0.15)+0.00065(\mathrm{SE}=0.0002) \times \mathrm{DCAD}(\mathrm{mEq} / \mathrm{kg}$ of $\mathrm{DM})]$, ionic calcium $[\mathrm{iCa} ; \mathrm{Y}=85.78(\mathrm{SE}=4.98)-0.08$ $(\mathrm{SE}=0.01) \times \mathrm{DCAD}(\mathrm{mEq} / \mathrm{kg}$ of $\mathrm{DM})+0.000237(\mathrm{SE}=0.00008) \times \mathrm{DCAD}^{2}\left(\mathrm{mEq} / \mathrm{kg}\right.$ of $\left.\mathrm{DM}^{2}\right), \mathrm{MUN}[\mathrm{Y}=18.22(\mathrm{SE}=1.36)+0.0094(\mathrm{SE}$ $=0.0026) \times \operatorname{DCAD}(\mathrm{mEq} / \mathrm{kg}$ of DM)], milk ethanol stability [MES; level of ethanol in alcohol solution necessary to cause milk precipitation; $\mathrm{Y}=74.87(\mathrm{SE}=0.87)+0.01174(\mathrm{SE}=0.0025) \times \mathrm{DCAD}(\mathrm{mEq} / \mathrm{kg}$ of DM)$)$, and coagulation time $[\mathrm{CT}$; necessary time to coagulate the milk during the heating at $140^{\circ} \mathrm{C} ; \mathrm{Y}=3.95(\mathrm{SE}=1.02)+0.01234(\mathrm{SE}=0.0032) \times \mathrm{DCAD}(\mathrm{mEq} / \mathrm{kg}$ of $\left.\mathrm{DM})\right]$ in milk.

nents, such as fat and protein. In our study, the milk content of lactose increased linearly in response to the DCAD increase. Similar results were observed by $\mathrm{Hu}$ et al. (2007), who reported that the concentration of lactose in milk increased linearly according to the increase of DCAD. The increased lactose content of the milk resulting from increased DCAD may be associated with increased DMI and greater availability of glucose in the mammary gland, as by reducing the DCAD the availability of acid in the blood can be increased due to high consumption of anions, which could hamper insulin activity and the entry of glucose into cells (Block, 1994).

As a result of the increase of milk fat and lactose content, the TS content also increased linearly according to the increase of DCAD. However, the milk content 
of SNF was not changed by diet. This may be a result of the negative effect of increased DCAD on the protein content, offset by an increase of the lactose milk content, which resulted in the lack of DCAD effect on milk SNF content. The reduction in CP content of milk in response to the increased DCAD probably occurred by linear reduction of milk content of casein. These results differ from those reported by $\mathrm{Hu}$ et al. (2007), who observed an increase in protein content of milk when evaluating DCAD of 30,220 , and $470 \mathrm{mEq} / \mathrm{kg}$ of DM. Otherwise, Hu and Murphy (2004) and Roche et al. (2005) found no effect of DCAD on the CP content of milk.

Milk mineral composition is relatively constant, but can vary according to the metabolic status of dairy cows. In our study, the reduction of DCAD only tended to alter the milk concentration of $\mathrm{Na}$ and $\mathrm{K}$, and did not change the $\mathrm{P}$ content. However, in the present study, chloride concentration in the milk was increased linearly as DCAD reduced. The increase in milk concentration of chloride may have occurred in response to metabolic acidosis resulting from the DCAD reduction, as the excretion of anions by body fluids, such as milk and urine, may be increased to compensate acidosis (Block, 1994). The iCa concentration in milk was high with the DCAD reduction. This result probably occurred through mechanisms controlled by hormones such as the parathyroid, calcitonin, and 1,25-dihydroxycholecalciferol, which may alter the intestinal absorption, bone reabsorption, and renal calcium excretion to increase the concentration of this mineral in the blood in an attempt to compensate for the metabolic acidosis (Block, 1994; Marques et al., 2011). As a result of this increase of $\mathrm{iCa}$ in blood, the concentration of $\mathrm{iCa}$ in milk may also be high with the metabolic acidosis (Marques et al., 2011). Using a different experimental design, Roche et al. (2005) reported no effects of high DCAD (230 to $880 \mathrm{mEq} / \mathrm{kg}$ of $\mathrm{DM}$ ) on the mineral composition of milk.

Calcium may be present in the colloidal phase (bound to casein micelles) or in the soluble phase of milk, and the ionic balance between these 2 phases and with other milk minerals is important to maintain casein stability. In the present study, in response to increasing iCa concentration of milk, the milk ethanol and heat stability were linearly reduced. A similar result was reported by Marques et al. (2011), who found decreased ethanol stability with increasing iCa concentration in milk. According to Barros et al. (1999), when milk concentrations of iCa increased a reduction was noted in the negative charges of casein micelles and in the electrostatic repulsion forces between them. Thus, increased iCa activity in milk may reduce the electrostatic and steric repulsion between casein micelles and probably increases their Van der Waals attraction, which may raise the micelle interactions and reduce the heat stability of milk (Jeurnink and De Kruif, 1995).

In addition to altering the ionic balance between the subunits of casein, the milk concentration of iCa may enhance the interactions between the $\kappa-\mathrm{CN}$, which is hydrophilic and stays in the outer layer of the micelle, and $\beta$-LG, which has reactivity with $\kappa-\mathrm{CN}$ and can be associated with milk stability. In our study, the milk content of $\kappa$-CN increased linearly with DCAD reduction. A similar result was described by Marques et al. (2011), who observed a trend $(P=0.09)$ for increased $\kappa-\mathrm{CN}$ content of milk from cows fed an anionic diet compared with milk from cows fed a cationic diet. In a different form, Roche et al. (2005) no found effects of high DCAD on the concentrations of casein subunits and whey proteins. In our study, the reduction of DCAD led to a linear decrease in the concentration of $\beta$-LG in milk. The $\beta$-LG shows reactivity with $\kappa-\mathrm{CN}$ in the micelle, with the intensity of interactions between these proteins depending on the milk concentration of free calcium (Singh and Fox, 1987). Jeurnink and De Kruif (1995) reported that $\beta$-LG might react in 3 ways with others proteins: forming aggregates with other $\beta$-LG molecules, forming a complex with $\kappa$ - $\mathrm{CN}$ at the surface of the casein micelle, and forming a complex with the $\kappa-\mathrm{CN}$ in the serum phase of milk. The milk concentration of free calcium is a factor that determines the intensity and the site of formation of protein complexes, and according to Jeurnink and De Kruif (1995) with increasing the calcium ion activity a $\beta-\mathrm{LG} / \kappa-\mathrm{CN}$ complex is formed at the surface of the casein micelle. Thus, in our study, in response to metabolic acidosis resulting from the DCAD reduction, the increase in iCa concentration in the milk may have enhanced the association of $\beta-\mathrm{LG}$ with $\mathrm{k}-\mathrm{CN}$ in the micelle, which can facilitate the formation of protein complex between these 2 proteins (Jeurnink and De Kruif, 1995; Holt et al., 2013).

Besides the iCa concentrations and interactions between milk proteins, other factors, such as the MUN concentration, can contribute to change the milk stability. In our study, the MUN concentration reduced according to the DCAD reduction, which may have contributed to reducing milk stability. The MUN can inhibit the formation of acids and act on the thiol groups of proteins. In addition, urea may be converted to cyanide, which unlike calcium, reacts with milk protein and increases the negative charges of the micelles, which increases the repulsive forces among them and, consequently, milk stability (Sweetsur and Muir, 1981).

The metabolic acidosis in lactating dairy cows can occur as a result of DCAD reduction or from ruminal acidosis or high metabolic rate of dairy cows (Barros 
et al., 1999; Marques et al., 2011; Fischer et al., 2012). Thus, diets with high levels of NFC or low eNDF may also contribute to the occurrence of low milk stability, as ruminal acidosis may result in metabolic acidosis (Ponce and Hernández, 2005; Fischer et al., 2012). Moreover, as described by Barbosa et al. (2012), the deficiency of dietary nutrients can also reduce milk stability. Stumpf et al. (2013) reported that feed restriction increases permeability of mammary gland cell tight junctions and reduces the MES, probably due a higher passage of ions to milk. Therefore, to prevent the occurrence of low milk stability, the high nutrient demand of lactating dairy cows must be met by the use of concentrated feeds; however, measures such as adequate supply of NDF or eNDF and the use of buffering or alkaline in the diet of dairy cows must be considered to avoid overproduction of VFA in the rumen fluid that can contribute to acidification and changes in the acid or base blood balance. Furthermore, changes in the forage or concentrated ingredients or mineral supplements without prior adaptation should also be avoided to prevent digestive problems (Fischer et al., 2012), changes in DCAD, and, consequently, problems of low milk stability.

In Brazil, the main exported dairy products are UHT milk, powdered milk, and condensed milk (Brazil, 2014); thus, milk instability causes high financials losses to the dairy agroindustrial chain (Fischer et al., 2012). Marques et al. (2007) reported that during a 17-mo evaluation period, $58 \%$ of the samples were unstable to the reaction with ethanol $(76 \% \mathrm{vol} / \mathrm{vol}$ ethanol in the alcohol solution), but without acquired acidity (titratable acidity average of $15.81^{\circ} \mathrm{D}$ ). The low stability of milk causes losses to the dairy farmers, who suffer a penalty in milk payment; for the dairy industry, which cannot use this low-stability milk for the production of dairy products, such as UHT and powdered milk; and for the consumer, as milk with low stability may have a reduced shelf life because the $\beta-\mathrm{LG} / \kappa-\mathrm{CN}$ complex can be formed during high temperature treatment of milk and can lead to irreversible gel formation during storage (i.e., micelle aggregation to form a continuous 3-dimensional network; McMahon, 1995; García-Risco et al., 1999; Holt et al., 2013). McMahon (1995) observed by electron micrographs that casein micelles from aged UHT milk sometimes reveal protuberances, spikes, or tendrils comprising complexes of $\beta-\mathrm{LG}$ and $\kappa-\mathrm{CN}$. According to McMahon (1995), during UHT milk storage at room temperature the casein micelle size increases, and some factors were associated with gelation, such as proteolysis, physiochemical changes, and aggregation of $\beta-\mathrm{LG} / \kappa-\mathrm{CN}$ complexes that form and subsequently dissociate from the casein micelle in UHT milk. Thus, the metabolic acidosis in lactating dairy cows may enhance the gel formation during milk storage, as the increased milk concentration of iCa may potentiate the $\beta$-LG and к-CN interaction (Hambling et al., 1992; Jeurnink and De Kruif, 1995)

In our study, a moderate correlation was observed between milk stability to ethanol and stability at $140^{\circ} \mathrm{C}$ ( $\mathrm{r}=0.45 ; P=0.01)$. Similar to our results, Molina et al. (2001) and Chavez et al. (2004) reported low or medium correlation between milk stability to ethanol and other heat treatment measurements, such as clotting on the boiling test and coagulation time. In many countries that use UHT as the main form of fluid milk processing, some dairy industries have been using higher ethanol concentrations (from 72 to $82 \%$ ) in the alcohol test aiming to select milk with high stability. However, the use of MES as a screening test for acceptance raw milk for heat processing may not provide satisfactory results, as MES had limited capacity to estimate milk heat stability. Thus, future studies are need to propose accurate and precise methods to estimate milk heat stability, which can improve the efficiency of dairy agroindustrial chain, as low-stability milk without acquired acidity by microbial contamination could be adequately identified and subjected to less intense heat processing, such as pasteurization (Fischer et al., 2012).

\section{CONCLUSIONS}

Concentrations of $\mathrm{iCa}$ and $\kappa-\mathrm{CN}$ in milk increase according to the DCAD reduction, whereas MUN and $\beta-\mathrm{LG}$ concentrations decrease. Because of these changes, milk stability to ethanol and during heating at $140^{\circ} \mathrm{C}$ is decreased linearly with DCAD reduction due to changes in the milk ionic balance and the interactions among the milk proteins in micelle. Thus, the results of the present study suggest that the control of metabolic changes in lactating dairy cows to maintain the blood acid-base status in equilibrium play an important role to maintain milk stable to ethanol and during heat treatments.

\section{ACKNOWLEDGMENTS}

We are grateful to FAPESP (Fundação de Amparo à Pesquisa do Estado de São Paulo, São Paulo, Brazil) for the research funding (Proc. 2012/23212-0) and for scholarships (2012/22165-9; 2013/07041-4 and 2013/02227-2). We also thank Ives Cláudio da Silva Bueno, José Garcia Moreno Franchini, Lucinéia Mestieri, Roice Eliana Rosim, and Priscila Sales Maldonado (University of São Paulo, São Paulo, Brazil) for technical assistance. 


\section{REFERENCES}

Allen, M. S. 1997. Relationship between fermentation acid production in the rumen and the requirement for physically effective fiber. J. Dairy Sci. 80:1447-1462. http://dx.doi.org/10.3168/jds.S00220302(97)76074-0.

AOAC International. 1995. Official Methods of Analysis. 16th ed. AOAC International, Arlington, VA.

Apper-Bossard, E., P. Faverdin, F. Meschy, and J. L. Peyraud. 2010. Effects of dietary cation-anion difference on ruminal metabolism and blood acid-base regulation in dairy cows receiving 2 contrasting levels of concentrate in diets. J. Dairy Sci. 93:4196-4210. http://dx.doi.org/10.3168/jds.2009-2975.

Barbosa, R. S., V. Fischer, M. E. R. Ribeiro, M. B. Zanela, M. T. Stumpf, G. J. Kolling, J. Schafhäuser Júnior, L. E. Barros, and A. S. Egito. 2012. Electrophoretic characterization of proteins and milk stability of cows submitted to feeding restriction. Pesqui. Agropecu. Bras. 47:621-628. http://dx.doi.org/10.1590/S0100204X2012000400019.

Barros, L., N. Denis, A. Gonzalez, and A. Núñez. 1999. Prueba del alcohol en leche y relación con calcio iónico. Pract. Vet. 9:13-15.

Bauman, D. E., and J. M. Griinari. 2003. Nutritional regulation of milk fat synthesis. Annu. Rev. Nutr. 23:203-227. http://dx.doi. org/10.1146/annurev.nutr.23.011702.073408.

Bentley Instruments. 1995. Bentley 2000: Operator's Manual. Bentley Instruments, Chaska, MN.

Bentley Instruments. 1998. Chemspeck 150: User's Guide. Bentley Instruments, Chaska, MN.

Block, E. 1994. Manipulation of dietary cation-anion difference on nutritionally related production diseases, productivity, and metabolic responses of dairy cows. J. Dairy Sci. 77:1437-1450. http:// dx.doi.org/10.3168/jds.S0022-0302(94)77082-X.

Bobe, G., D. C. Beitz, A. E. Freeman, and G. L. Lindberg. 1998. Separation and quantification of bovine milk proteins by reversed-phase high performance liquid chromatography. J. Agric. Food Chem. 46:458-463. http://dx.doi.org/10.1021/jf970499p.

Brazil. 2014. Ministry of Development, Industry and Foreign Trade. Secretariat of Foreign Trade (SECEX), of the Ministry of Development, Industry and Foreign Trade. System of Foreign Trade Information Analysis-Mercosur-AliceWeb Mercosul. Accessed May 20, 2014. http://www.aliceweb2.mdic.gov.br/.

Chavez, M. S., L. M. Negri, M. A. Taverna, and A. Cuatrín. 2004. Bovine milk composition parameters affecting the ethanol stability. J. Dairy Res. 71:201-206. http://dx.doi.org/10.1017/ S0022029904000172.

Creamer, L. K., J. E. Plowman, M. J. Liddell, M. H. Smith, and J. P. Hill. 1998. Micelle stability: $\alpha$-casein structure and function. J. Dairy Sci. 81:3004-3012. http://dx.doi.org/10.3168/jds.S00220302(98)75864-3.

Delaquis, A. M., and E. Block. 1995. The effects of changing ration ingredients on acid-base status, renal function, and macromineral metabolism. J. Dairy Sci. 78:2024-2039. http://dx.doi. org/10.3168/jds.S0022-0302(95)76828-X.

Fischer, V., M. E. R. Ribeiro, M. B. Zanela, L. T. Marques, A. S. Abreu, S. C. Machado, V. Fruscalso, R. S. Barbosa, and M. T. Stumpf. 2012. Unstable nonacid milk: A solvable problem? Rev. Bras. Saúde . Prod. Anim. 13:838-849. http://dx.doi.org/10.1590/ S1519-99402012000300021.

Foss Analytical. 2008. MilkoScan 6000 FT+: Operator's manual. Foss Analytical, Hillerød, Denmark.

García-Risco, M. R., M. Ramos, and R. López-Fandinõ. 1999. Proteolysis, protein distribution and stability of UHT milk during storage at room temperature. J. Sci. Food Agric. 79:1171-1178.

Hall, M. B. 2000. Neutral Detergent-Soluble Carbohydrates. Nutritional Relevance and Analysis. University of Florida, Gainesville.

Hambling, S. G., A. S. McAlpine, and I. Sawyer. 1992. Beta-lactoglobulin. Pages 141-189 in Advanted Dairy Chemistry. Vol. 1. P. F. Fox, ed. Elsevier Applied Science London, UK.

Holt, C., J. A. Carver, H. Ecroyd, and D. C. Thorn. 2013. Invited review: Caseins and the casein micelle: Their biological functions, structures, and behavior in foods. J. Dairy Sci. 96:6127-6146 http://dx.doi.org/10.3168/jds.2013-6831.

Hu, W., and M. R. Murphy. 2004. Dietary cation-anion difference effects on performance and acid-base status of lactating dairy cows. A meta-analysis. J. Dairy Sci. 87:2222-2229. http://dx.doi. org/10.3168/jds.S0022-0302(04)70042-9.

Hu, W., M. R. Murphy, P. D. Constable, and E. Block. 2007. Dietary cation-anion difference and dietary protein effects on performance and acid-base status of dairy cows in early lactation. J. Dairy Sci. 90:3355-3366. http://dx.doi.org/10.3168/jds.2006-514.

Jeurnink, T. J. M., and C. G. De Kruif. 1995. Calcium concentration in milk in relation to heat stability and fouling. Neth. Milk Dairy J. 49:151-165.

Lewis, M. J. 2011. The measurement and significance of ionic calcium in milk - review. Int. J. Dairy Technol. 64:1-13. http://dx.doi. org/10.1111/j.1471-0307.2010.00639.x.

Malavolta, E., G. C. Vitti, and S. A. Oliveira. 1997. Assessment of Nutritional Status of Plants: Principles and Applications. 2th ed. Brazilian Association for Research Potash and Phosphate. Piracicaba, Brazil.

Marques, L. T., V. Fischer, M. B. Zanela, M. E. R. Ribeiro, W. Stumpf Junior, and C. M. Rodrigues. 2011. Milk yield, milk composition and biochemical blood profile of lactating cows supplemented with anionic salt. R. Bras. Zootec. 40:1088-1094. http://dx.doi. org/10.1590/S1516-35982011000500021.

Marques, L. T., M. B. Zanela, M. E. R. Ribeiro, W. Stumpf Junior, and V. Fischer. 2007. Occurrence of unstable to alcohol $76 \%$ and non-acid milk (lina) and influence on physicochemical aspects of milk. Rev. Bras. Agrocienc. 13:91-97.

McMahon, D. J. 1995. Age gelation of UHT milk: Changes that occur during storage, their effect on shelflife and the mechanism by which age gelation occurs. Pages $315-326$ in Heat Treatments and Alternative Methods, International Dairy Federation. Brussels, Belgium.

Mertens, D. R. 2002. Gravimetric determination of amylase-treated neutral detergent fiber in feeds with refluxing in beakers or crucibles: Collaborative study. J. AOAC Int. 85:1217-1240.

Molina, L. H., R. Gonzáles, C. Brito, B. Carrillo, and M. Pito. 2001 Correlation between heat stability and alcohol test of milks at a milk collection center. Arch. Med. Vet. 33:233-240. http:// dx.doi.org/10.4067/S0301-732X2001000200012.

National Research Council. 2001. Nutrient Requirements of Dairy Cattle. 7th rev. ed. Natl. Acad. Press, Washington, DC.

Negri, L., M. Chavez, M. Taverna, A. Cuatrín, and A. Rubiolo. 2003. Determination of variables affecting thermal milk stability using a capillary method for evaluation of thermal coagulation time. Rev. Argent. Lactol. 22:33-44.

Oliveira, C. A. F., L. C. Lopes, R. E. Rosim, A. M. Fernandes, and C. H. Corassin. 2013. Composition, somatic cell count and casein fractions of ethanol unstable milks. Acta Sci. Technol. 35:153156. http://dx.doi.org/10.4025/actascitechnol.v35i1.11481.

Ponce, P. C., and R. Hernández. 2005. Effect of three diet types on the appearance of metabolic dysfunctions and their relationship with alterations in milk composition of Holstein Friesian cows. Zootec. Trop. 23:295-310.

Roche, J. R., S. Petch, and J. K. Kay. 2005. Manipulating the dietary cation-anion difference via drenching to early-lactation dairy cows grazing pasture. J. Dairy Sci. 88:264-276. http://dx.doi. org/10.3168/jds.S0022-0302(05)72684-9.

Sharif, M., M. A. Shahzad, Mahr-un-Nisa, and M. Sarwar. 2010 Dietary cation anion difference: Impact on productive and reproductive performance in animal agriculture. Afr. J. Biotechnol. 9:7976-7988. http://dx.doi.org/10.5897/AJB09.1926.

Singh, H. 2004. Heat stability of milk. Int. J. Dairy Technol. 57:111119. http://dx.doi.org/10.1111/j.1471-0307.2004.00143.x.

Singh, H., and P. Fox. 1987. Heat stability of milk: Role of $\beta$-lactoglobulin in the $\mathrm{pH}$-dependet dissociation of micellar $\kappa$-casein. J. Dairy Res. 54:509-521. http://dx.doi.org/10.1017/S0022029900025711.

Sklan, D., M. Kaim, U. Moallem, and Y. Folman. 1994. Effect of dietary calcium soaps on milk yield, bodyweight, reproductive hormones 
and fertility in first parity and older cows. J. Dairy Sci. 77:16521660. http://dx.doi.org/10.3168/jds.S0022-0302(94)77107-1.

Stumpf, M. T., V. Fischer, C. M. McManus, G. J. Kolling, M. B. Zanela, C. S. Santos, A. S. Abreu, and P. Montagner. 2013. Severe feed restriction increases permeability of mammary gland cell tight junctions and reduces ethanol stability of milk. Animal 7:11371142. http://dx.doi.org/10.1017/S1751731113000128.

Sweetsur, A. W. M., and D. D. Muir. 1981. Role of cyanate ions in the urea-induced stabilization of the caseinate complex in skimmilk. J. Dairy Res. 48:163-166. http://dx.doi.org/10.1017/ S0022029900021579.

Thermo Fisher Scientific. 2008. iCE 3000 Series Atomic Absorption Spectrometers: Operators Manual. Thermo Fisher Scientific, Cambridge, UK.

Tucker, W. B., J. F. Hogue, D. F. Waterman, T. S. Swenson, Z. Xin, R. W. Hemken, J. A. Jackson, G. D. Adams, and L. J. Spicer. 1991.
Role of sulfur and chloride in the dietary cation-anion balance equation for lactating dairy cattle. J. Anim. Sci. 69:1205-1213.

Van Soest, P. J., J. B. Robertson, and B. A. Lewis. 1991. Symposium: Carboydrate metodology, metabolism, and nutritional implications in dairy cattle. J. Dairy Sci. 74:3583-3597.

Walstra, P. 1999. Casein sub-micelles: Do they exist? Int. Dairy J. 9:189-192. http://dx.doi.org/10.1016/S0958-6946(99)00059-X.

West, J. W., B. G. Mullinix, and T. G. Sandifer. 1991. Changing dietary electrolyte balance for dairy cows in cool and hot environments. J. Dairy Sci. 74:1662-1674. http://dx.doi.org/10.3168/ jds.S0022-0302(91)78329-X.

Zanela, M. B., V. Fischer, M. E. R. Ribeiro, R. S. Barbosa, L. T. Marques, W. Stumpf Junior, and C. Zanela. 2006. Unstable nonacid milk and milk composition of Jersey cows on feed restriction. Pesquisa Agropecu. Bras. 41:835-840. http://dx.doi.org/10.1590/ S0100-204X2006000500016. 